\title{
ИННОВАЦИОННЫЕ МЕТОДЫ РАБОТЫ С ПОДРОСТКАМИ «ГРУППЫ РИСКА»
}

\author{
Гурман Юлия Давыдовна \\ Попова Наталья Николаевна \\ педагоги-психологи \\ ГБОУ Гимназия 587 Санкт-Петербурга
}

Аннотация: В статье раскрываются особенности подросткового периода. Приведена практика разработки проекта работы с подростками «группы риска», выявленной по результатам проведенной диагностики.

Ключевые слова: Подростки, девиантное поведение, внеурочная деятельность, тренинг, консультирование.

Abstract: The article reveals the features of the adolescent period. The practice of developing a project for working with adolescents of the "risk group" identified by the results of the diagnosis is presented.

Key words: Adolescents, deviant behavior, extracurricular activities, training, counseling.

\section{Опыт работы педагогов-психологов по профилактике девиантного поведения подростков}

Психология подросткового возраста - один из самых сложных и наименее разработанных разделов возрастной психологии. Подростковый период - это время завершения детства и начало длительного периода перехода к взрослости. Он характеризуется «интенсивным процессом психического и личностного развития, физического созревания организма подростка. Происходящие с ним перемены осознаются и переживаются подростком, у него формируется новое представление о себе, укрепляется самооценка. Возрастные особенности отражают устойчивые свойства и качества личности, характерные для детей того или иного периода развития.

В настоящее время наблюдается повышенный интерес к проблеме отклоняющегося поведения подростков. Одной из серьезных проблем подросткового периода являются различные формы девиантного поведения подростков. Оно может выражаться в самых разных поступках, начиная с 
того, что подросток курит, употребляет наркотики, убегает из дома и кончая разбойными нападениями, или убийствами.

Девиантное поведение (англ. deviation - отклонение) - действия, не соответствующие официально установленным или фактически сложившимся в данном обществе (социальной группе) моральным и правовым нормам.[1] Также девиантное поведение - это результат неправильного развития личности, и именно у подростков наблюдаются первые проявления отклоняющегося поведения [2]. В большинстве случаев оно объясняется низким уровнем интеллектуального развития, отрицательным влиянием семьи, друзей, сбоями в процессе социализации.

Девиантное поведение, в настоящее время носит массово-системный характер. По данным представителя ФСИН Шамсунова, несовершеннолетние граждане РФ совершают ежегодно около 150 тысяч преступлений, что составляет примерно $10 \%$ от общего числа криминальных проявлений в стране [3].

Э. Кречмер и Х. Шелдон [4] выделяют два вида девиации. Положительная девиация воспринимается многими как необычное, не соответствующее окружающим поведение, но в основном, не вызывает неодобрения. Положительная девиация может быть связана со стремлением личности к новому, попыткой преодолеть консервативное, мешающее двигаться вперед, а также героические поступки, гениальность, самопожертвование, обострённое чувство жалости, преданность чему-либо или кому-либо.

Отрицательная девиация наоборот влечёт за собой у большинства людей реакцию неодобрения или осуждения (сюда можно отнести терроризм, вандализм, воровство, жестокое обращение с животными, предательство, обман и т.д.).

Отклоняющееся поведение в подростковом возрасте несет бОльшую опасность, чем в детском. Во-первых, потому что подросток может совершать более разрушительные действия. Во-вторых, потому что корректировка подобных явлений требует активных действий и длительного времени. Раскрытие сути отклоняющегося поведения предполагает поиск его источников. Необходимо понимать причины возникновения девиаций и психологические особенности несовершеннолетних.

Для выяснения источника отклоняющегося поведения или склонности к таковому ежегодно проводится социально-психологическое тестирование 
(СПТ). Проведение СПТ является неотъемлемым элементом плана воспитательной работы образовательной организации, обеспечивающей системное выявление обучающихся «группы риска» по вовлечению в девиантное поведение, организации с ними соответствующей профилактической, коррекционной работы.

Методика осуществляет оценку вероятности вовлечения в аддиктивное (зависимое) поведение на основе соотношения факторов риска и факторов защиты, воздействующих на обследуемых. Выявляет повышенную и незначительную вероятность вовлечения в зависимое поведение.

В тестировании оцениваются следующие факторы:

- Потребность в одобрении;

- Подверженность влиянию группы;

- Принятие адиктивных установок социума;

- Склонность к риску;

- Импульсивность;

- Тревожность;

- Принятие родителями;

- Принятие одноклассниками;

- Социальная активность;

- Самоконтроль поведения.

Анализируя полученные результаты, педагоги-психологи обращают особое внимание на учащихся, которые показали повышенные результаты по склонности к риску, импульсивности, тревожности, а также низкие показатели по принятию родителями и одноклассниками, самоконтролю поведения.

Учитывая данные показатели, а также на основании дополнительных исследований и других проведенных мероприятий (беседы с учащимися, консультации с родителями и педагогами) педагогами-психологами была выделена «группа риска», в которую вошли 12 учеников 9-11 классов.

Педагогами-психологами Гимназии был разработан пилотный проект по сопровождению учеников «группы риска».

Цель пилотного проекта - получение дополнительной информации о состоянии учащихся; безопасное включение учащихся в работу; использование результатов тестирования как повода для обратной связи и поддерживающего диалога. 


\section{Этапы пилотного проекта:}

1. Разработана программа дополнительной диагностики учащихся «группы риска», основываясь на результатах СПТ.

2. Проведены беседы с педагогами и консультации с родителями учащихся вошедших в «группу риска».

3. Разработаны программы индивидуального сопровождения этих учащихся по оказанию им психолого-педагогической помощи и коррекционного сопровождения.

4. Организована обратная связь по результатам дополнительной диагностики, индивидуальные консультации.

5. Разработан цикл тренингов для коррекции выявленных показателей повышенной вероятности вовлечения в зависимое поведение.

По мнению педагогов-психологов, разработавших пилотный проект для работы с «группой риска» необходимо, кроме стандартных инструментов (беседы, консультирование и т.д.) использовать инновационные методы работы, которые позволяют вовлечь учащихся в развитие через собственный опыт, повысить осознанность участников, сориентировать на поиск ресурсов для личностного роста.

Первым из цикла тренингов было разработано вводное занятие «Познай себя» в котором были использованы два инновационных метода как работа со сказками в виде метафорической деловой игры и LEGO-технологии. В работе, в качестве метафорической деловой игры, использовалась сказка «Гадкий утенок» Г.Х. Андерсена.

Почему именно эти методы?

Технология LEGO позволяет участникам тренинга отключить стереотипность мышления, стимулирует творческое мышление, участники «думают руками», а метафорическая деловая игра дает возможность посмотреть на ситуацию и себя со стороны, позволяет изменить установку участников, перевести фокус внимания на видение возможностей, почувствовать собственные ресурсы.

При формировании группы участников тренинга «Познай себя» с использованием LEGO-технологии и метафорической деловой игры к участникам из «группы риска» были дополнены волонтеры - ученики 10-х классов (4 человека: 2 мальчика и 2 девочки). Участие волонтеров позволило создать на тренинге атмосферу открытости и доверия.

Процедура поведения тренинга: 
- Введение в тренинг (знакомство, цель тренинга, правила работы).

- Разминка с конструктором LEGO. Строительство образа кошки их ограниченного количества элементов LEGO.

- Строительство образа «Гадкого утенка» (количество элементов LEGO не ограничено).

- Строительство общего дома для утят (коллективная работа).

- Реконструкция «Гадкого утенка» для самостоятельной жизни вне общего дома.

- Обсуждение, выводы.

В результате работы на тренинге было получено полное вовлечение участников в работу, возможность самовыражения. В ходе тренинга все учащиеся активно участвовали в работе, ассоциировали себя с утятами (при обсуждении образа утенка часто говорили: «Я»). Были созданы условия для анализа себя, своих возможностей уже в процессе работы. В конце тренинга, при реконструкции Гадкого утенка в самостоятельного Лебедя, участники отметили, что задумались о себе, стали понятнее сами себе, у них появились мысли о том, что делать дальше. У участников сформировалась готовность к дальнейшей работе над собой и самосовершенствованию.

По окончании тренинга, были совместно педагогами-психологами и участниками сформулированы темы тренингов для дальнейшей работы. Важно отметить, что они совпали с темами цикла тренингов, которые запланировали педагоги-психологи, основываясь на результатах диагностики, на этапе создания пилотного проекта. Многие участники тренинга проговорили свою готовность к дальнейшей работе, также были озвучены просьбы на индивидуальное консультирование.

По окончании пилотного проекта было решено не проводить повторную диагностику, а оценить результаты работы по обратной связи от педагогов, родителей и учащихся (не только «группы риска»). Было выявлено, что многие проблемы, которые были озвучены и диагностированы в начале проекта стали значительно слабее выражены, у участников снизился уровень тревожности и улучшились взаимоотношения с родителями и одноклассниками.

\section{Список литературы}

(1) Большой психологический словарь. - М.: Прайм-ЕВРОЗНАК. Под ред. Б.Г. Мещерякова, акад. В.П. Зинченко. 2003. 
(2) Энциклопедический словарь по психологии и педагогике, Под редакцией М. И. Еникеева, 2013, 540 с.

(3) Горшков М.К., Шереги Ф.Э. Молодежь России: социологический портрет. - 2-е издание, дополненное и исправленное. - М.: Институт социологии РАН, 2013. - 592 с.

(4) Кречмер Э., Строение тела и характер: Переведено с немецкого. M., 2005. - 280 c. C- 192.

(С Ю.Д. Гурман, Н.Н. Попова, 2021 